\title{
UPLIFT AND DENUDATION OF THE TETON RANGE, WYOMING
}

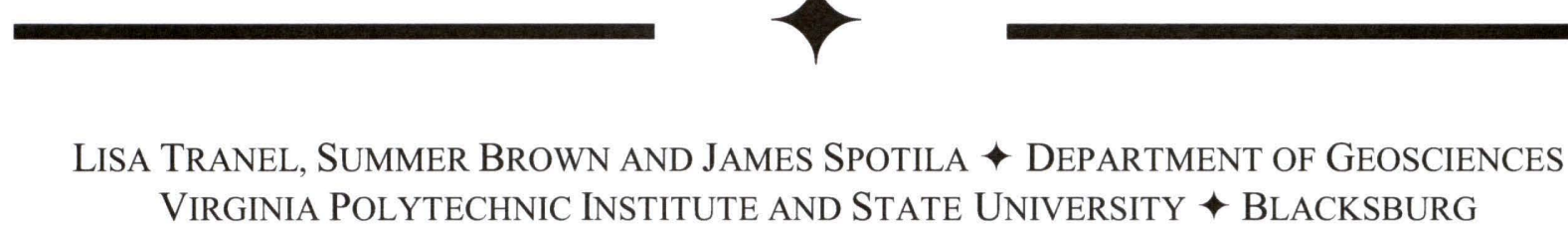
VIRGINIA POLYTECHNIC INSTITUTE AND STATE UNIVERSITY $\downarrow$ BLACKSBURG

\section{$+\quad$ INTRODUCTION}

Our research group is interested in understanding the development of the dramatic relief of the Teton Range. In similar settings worldwide, relief has been examined as product of uplift and denudation. Therefore, we are combining tectonic and geomorphic studies to identify the progression of erosional processes from glacial to interglacial climates and also to refine the uplift history. By integrating these fields, we hope to gain a better understanding of the evolution of the Teton landscape.

\section{PROJECT 1}

\section{$\downarrow$ BACKGROUND AND OBJECTIVES}

The purpose of the first project is to quantify erosion rates of individual geomorphic processes to see how each contributes to the evolution of relief and topography in mountain ranges. During the last glacial maximum, significant volumes of material were removed from the base of canyons in the Teton Range, creating high relief and over steepened canyon walls. Although glaciers have disappeared from most canyons, features created by those glaciers still affect present erosional processes. We hypothesize that fluvial and mass wasting processes contribute to the high relief of these mountains since the last glacial maximum. To understand the effectiveness of each process, we are studying mass wasting, fluvial erosion, and weathering of bedrock surfaces with field observations, detrital (U$\mathrm{Th} / \mathrm{He}$ thermochronometry and cosmogenic radionuclide surface ages.

To understand how landscape evolves in response to climate change, we need to quantify how much erosion occurs by glacial, fluvial, and mass wasting processes in known climate conditions. Small et al. (1997) studied differential erosion of basins and summits in the Wind River and Beartooth Ranges and revealed that topographic relief increases because erosion is more efficient in basins than on summits. In contrast, Stock et al. (2006) concluded that streams erode uniformly within fluvial mountain catchments. In complex environments, there is still much work to be done to understand how individual processes interact with each other and tectonic processes.

The Teton Range is a unique landscape with significant topographic relief and interesting tectonic and geomorphic history. Roberts and Burbank (1993) studied tectonic uplift in this range with apatite fission track dating. Their results indicate uplift on this range began with Laramide folding and continued with Basin and Range extension. Hampel et al. (2007) modeled uplift on the Teton Fault and found that uplift likely increased as a result of deglaciation of the Yellowstone ice cap. Foster et al. (2007) modeled characteristics of canyons within mountain ranges of the Northeastern Basin and Range. Comparing hypsometry and alongcanyon profiles, they found that the landscape in the Teton Range differs from other ranges in the region. They suggested that this difference may reflect a response to climatic conditions.

We are using field evidence of erosion in canyons to determine how climatic and uplift events influenced physical erosion of bedrock in canyons. This is an ideal location because previous tectonic and glacial histories have been well constrained. Several canyon streams drain into lakes trapped by end moraines in Jackson Hole. These lakes trap sediments 
derived from the canyons, so it is ideal to study the erosional histories since the last glacial maximum $\sim 14$ $\mathrm{ka}$ (Licciardi et al, 2008). Determining the efficacy of each erosional process will help us understand climatic and tectonic influences on landscape found in previous studies.

\section{$\uparrow \quad$ METHODS}

During July and August 2008 we surveyed talus fans in Avalanche Canyon and Glacier gulch to quantify denudation by rockfall in the Teton Range. We used a laser range finder to measure the width and length of fans and place them on geomorphic maps (Figure 1). We also measured the slope of the bedrock on the rock walls above the talus fans with the laser range finder to project the angle of the bedrock surface below the deposits. This allowed us to estimate thickness of material within the fan deposits. With the length, width, and thickness, we calculated volumes for each talus fan we surveyed in these two canyons. We digitized our data in ArcMap and used ArcMap to calculate the contributing bedrock surface area. The total amount of material eroded from the ridges was calculated by dividing the talus fan volume by the contributing bedrock surface area. That value was then divided by $\sim 14 \mathrm{ka}$ to determine an erosion rate on the ridge based on the time when glacial retreat began as measured by Licciardi et al (2001).
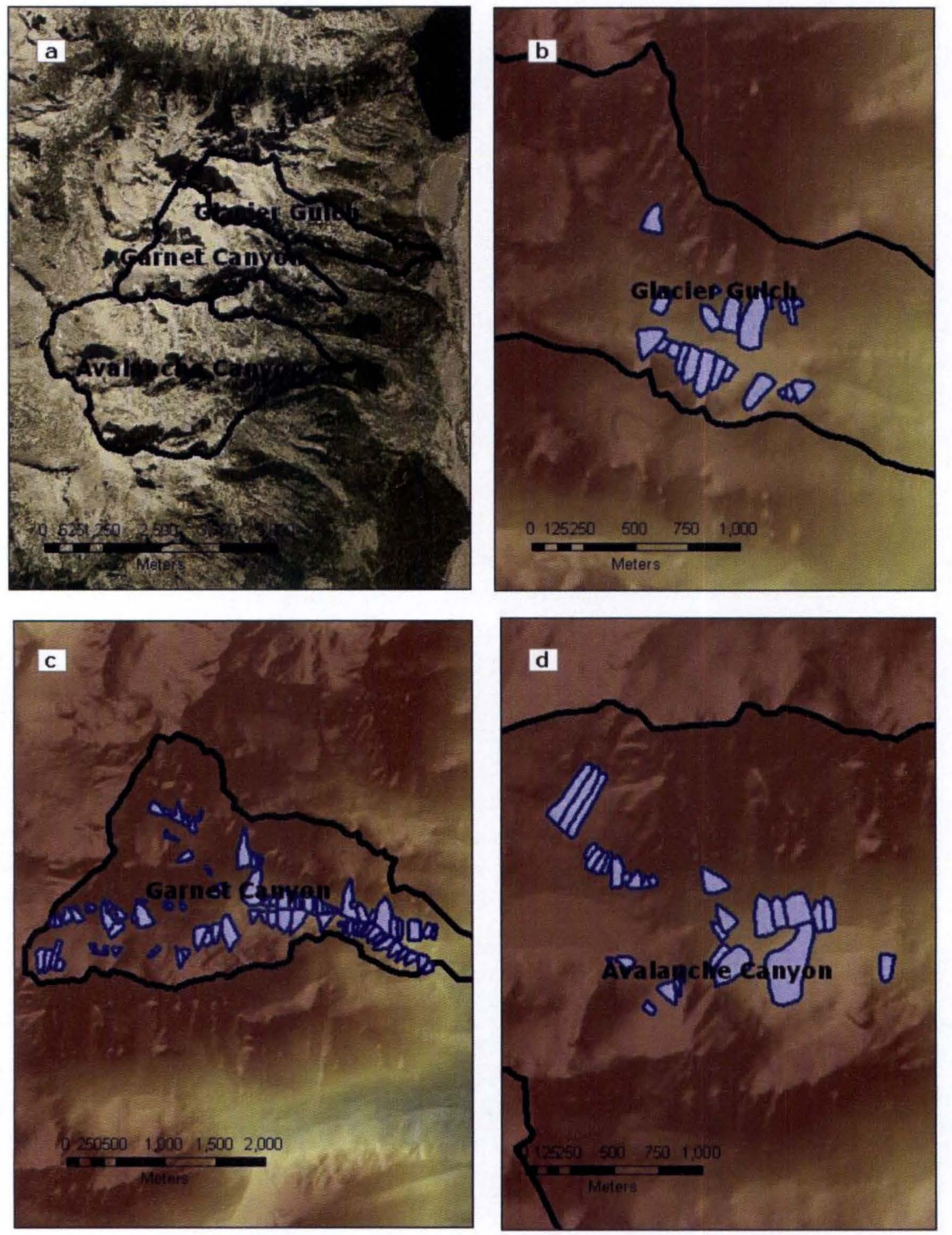

Figure 1: Talus deposits were surveyed in Glacier Gulch, Garnet Canyon, and Avalanche Canyon. a) Locations of the three canyons mapped on an aerial photograph. b) Talus fans mapped in Glacier Gulch. c) Talus fans mapped in Garnet Canyon d) Talus fans mapped in the North Fork of Avalanche Canyon mapped on a digital elevation map. 
We also collected rock samples to measure the weathering rate on bedrock surfaces on ridges between the canyons. Bedrock surface weathering is measured with in situ cosmogenic radionuclides (CRN). Rocks exposed at the surface experience bombardment by cosmic rays from the sun, producing ${ }^{10} \mathrm{Be}$ in quartz grains. CRN concentration increases with time if rock is continuously exposed to these rays. Measuring isotopes present in quartz grains approximates the exposure age of a rock (Nishiizumi et al. 1993). CRN exposure ages will be determined by extracting quartz grains from rock samples and measuring ${ }^{10} \mathrm{Be}$ concentration. Nishiizumi et al. (1993) calculated an erosion rate of $0.048 \mathrm{~mm} / \mathrm{yr}$ in the Teton Range based on a single CRN exposure age. We collected a number of ridge samples to test if this rate is consistent across the range.

Since talus deposits are prevalent in the canyons, it appears that rockfalls are common. We tested rock strength in several areas in the three canyons to see if certain rocks might be more susceptible to slope failures or surface weathering. We used a Schmidt hammer to determine rock mass strength. We also measured joint widths, spacing, and dips to characterize the rock surfaces and fractures.

We collected sediment samples at the mouth of several canyon streams to determine fluvial erosion rates. These rates will be measured with CRN concentrations and detrital apatite grains in stream sediments. CRN in deposited quartz grains will be measured using the above methods. CRN ages are integrated to determine canyon-wide erosion rates (Binnie et al. 2006; Nishiizumi et al. 1993). Detrital apatite grains from sediment samples will be dated with (U-Th)/He thermochronometry (AHe) to identify the spatial distribution of erosion. AHe ages from rocks collected along vertical transects in our other project will be used to identify the distribution of ages in bedrock within the canyons. The age-elevation gradient combined with the elevation hypsometry of the drainage areas predicts the AHe age distribution expected from sediment grains if erosion is uniform (Brewer et al. 2003; Ruhl and Hodges 2005; Stock et al. 2006). Sediment ages from streams and glacial moraines compared to the predicted distribution will identify the concentration of erosion in the current system and during the last glacial maximum.

\section{PROJECT 2}

\section{$\downarrow \quad$ BACKGROUND AND OBJECTIVES}

The purpose of the second project is to refine the temporal and spatial uplift history of the Teton Range by combining (U-Th)/He and fission-track dating of apatite. Currently, the low-temperature thermochronological history of the Teton Range is notably limited. Among the youngest of the Rocky Mountain ranges, the Tetons likely experienced the majority of their uplift in the past 5 to 10 million years (Love et al. 2003), resulting in the present rugged landscape. Although the range-front Teton fault plays an important role in the evolution of the Teton Range, the age and displacement are still controversial. Previous research utilized inverse ray-tracing and gravity models to derive a total throw of $2.5-3.5 \mathrm{~km}$ and a fault initiation at 2-3 Ma (Byrd et al., 1994). Other data suggests that the Teton fault actually became active between 5 and $13 \mathrm{Ma}$, resulting in a total displacement of 6-9 km. Consequently, disputes exist regarding the long-term vertical slip rate, ranging from 0.5 to $1.2 \mathrm{~mm} / \mathrm{yr}$ (Smith et al., 1993; Byrd et al., 1994).

Roberts and Burbank (1993) analyzed apatite fission-tracks (AFT) in the Teton Range to determine the timing and pattern of exhumation and uplift. However, advances in the use of fission-track dating, and more specifically the concept of an exhumed partial annealing zone (PAZ) by Fitzgerald et al. (1995), in addition to the renaissance of apatite (U-Th)/ $\mathrm{He}(\mathrm{AHe})$ techniques (e.g. Farley, 2000), have redefined the expectations of a comprehensive thermochronological study. For fission-track dating, apatite has a closure temperature of $\sim 110^{\circ} \mathrm{C}$, implying that AFT ages from the previous transects do not clearly define the onset of Teton uplift because there is no record of cooling below $\sim 110^{\circ} \mathrm{C}$. Since many important tectonic and erosional processes occur in the upper $5 \mathrm{~km}$ of the crust, it is necessary to incorporate other methods to bridge gaps left by previous low-temperature studies. Because of the current studies involving interaction between climate and tectonics, it is important to document the latest stages of exhumation and denundation. While $(\mathrm{U}-\mathrm{Th}) / \mathrm{He}$ dating is applicable in a series of different minerals (i.e. zircon, titanite), apatite is particularly useful because of its exceptionally low closure temperature of $\sim 75^{\circ} \mathrm{C}$ and $\mathrm{He}$ partial retention zone (conceptually analogous to the $\mathrm{PAZ}$ ) between $\sim 40-75^{\circ} \mathrm{C}$ (Zeitler, et al., 1987; Lippolt et al., 1994; Wolf et al., 1998; Farley, 2000). Previously, AFT and AHe techniques have been successfully integrated to reconstruct exhumational histories (Crowley et al., 2002) and to deduce timing, rate, and extent of motion on normal fault systems (Ehlers et al., 2003; Stockli et al., 2000; Armstrong et al., 2003) 


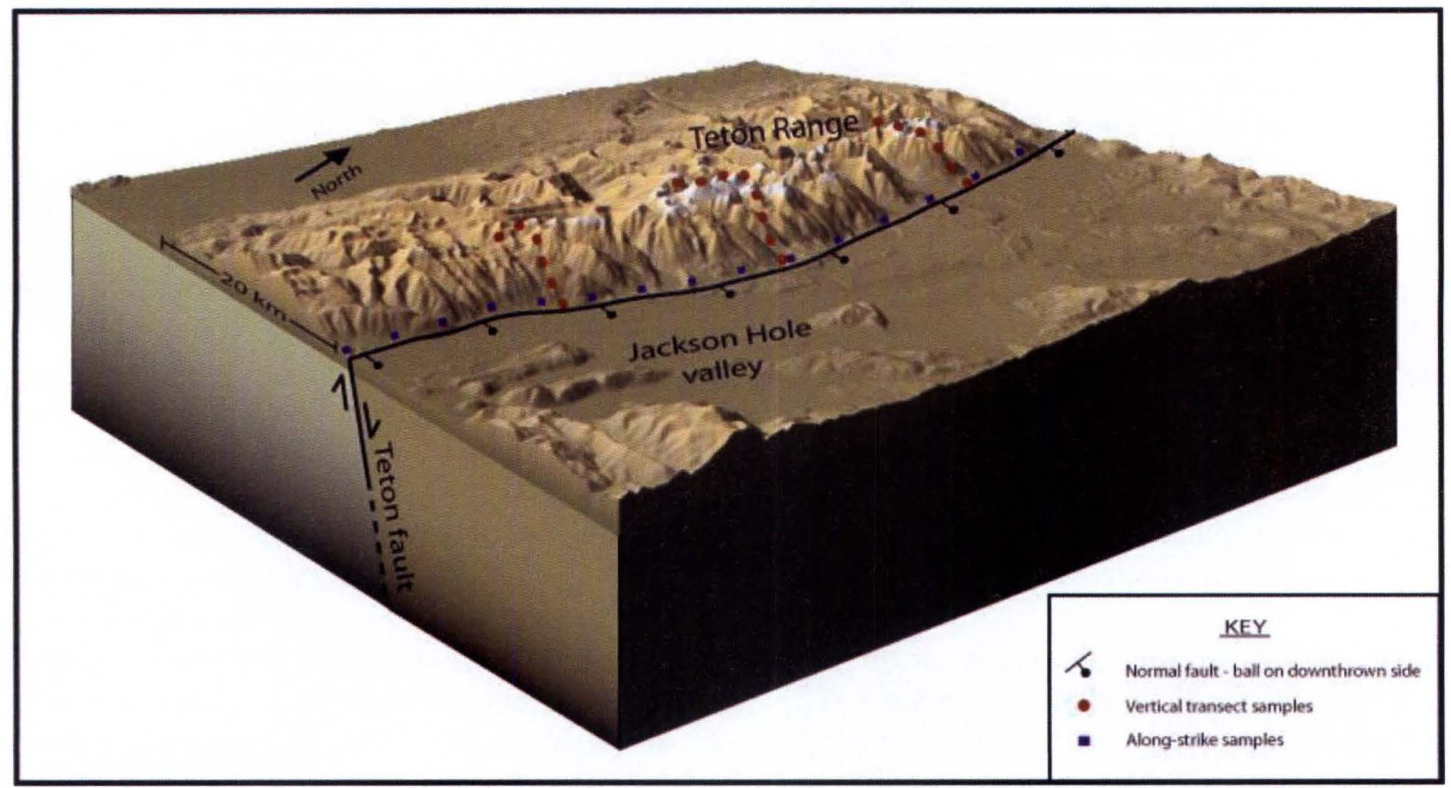

Figure 2 - Simplified model showing the relationship between the Teton Range and the normal Teton fault. Red and blue points represent approximate sample transects collected during August of 2008. Vertical exaggeration is 1.5.

\section{$\downarrow$ METHODS}

During August of 2008, approximately 20 bedrock samples were collected in three vertical transects across the Teton Range (Figure 2). Excluding late faulting or intrusive events, samples collected from higher elevations retain older ages, and the data shows a gradual increasing trend. However, if an episode of rapid uplift occurs, the data exhibits a visible inflection point. Thus, the information obtained from a series of vertical transects will help determine the uplift history prior to initiation of the Teton fault, timing of onset of movement along the fault, and will establish an ageelevation gradient throughout the Teton Range.

In addition, 16 bedrock samples were collected at low elevations parallel to the Teton fault. These samples will aid in identifying the age where inflection occurs at different locations along strike. This is important for determining if the progression of uplift along the Teton escarpment was along-strike growth or a constant-length increase in relief and offset, ideally leading to a greater understanding of the temporal and spatial evolution of normal fault blocks. Coupled with the exhumation history from the vertical transects, this data will provide essential insight into the creation of the Teton landscape.

\section{$\uparrow \quad$ Literature Cited}

Armstrong, P.A., T.A. Ehlers, D.S. Chapman, K.A. Farley and P.J. Kamp. 2003. Exhumation of the central Wasatch Mountains, Utah: 1. Patterns and timing deduced from low-temperature thermochronology data. Journal of Geophysical Research 108 doi:10.1029/2001JB001708

Binnie, S.A., W.M Philips, M.A. Summerfield and L.K. Fifield. 2006. Sediment mixing and basin-wide cosmogenic nuclide analysis in rapidly eroding mountainous environments: Quaternary Geochronology. 1:1-14.

Brewer, I.D., D.W Burbank and K.V. Hodges. 2003. Modelling detrital cooling-age populations: insights from two Himalayan catchments: Basin Research. 15(3):305-320.

Byrd, J.O.D., R.B. Smith and J.W. Geissman. 1994. The Teton fault, Wyoming: Topographic signature, neotectonics, and mechanisms of deformation: Journal of Geophysical Research. 99(B10):20,095-20,122.

Crowley, P.D., P.W. Reiners, J.M. Reuter and G.D. Kaye. 2002. Laramide exhumation of the Bighorn Mountains, Wyoming: An apatite (U$\mathrm{Th} / \mathrm{He}$ thermochronology study: Geology, 30(1):27-30. 
Ehlers, T.A., S.D. Willett, P.A. Armstrong and D.S. Chapma. 2003. Exhumation of the central Wasatch Mountains, Utah: 2. Thermokinematic model of exhumation, erosion, and thermochronometer interpretation: Journal of Geophysical Research. 108(B3):2173.

Farley, K.A. 2000. Helium diffusion from apatite: general behavior as illustrated by Durango fluorapatite: Journal of Geophysical Research. 105:2903-2914.

Fitzgerald, P.G., R.B. Sorkhabi, T.F. Redfield and E. Stump. 1995, Uplift and exhumation of the central Alaska Range: A case study in the use of apatite fission track thermochronology to determine absolute uplift parameters: Journal of Geophysical Research. 100:20,175-20,191.

Foster, D., S.H. Brocklehurst and R.L. Gawthorpe. 2008. Small valley glaciers and the effectiveness of the glacial buzzsaw in the northern Basin and Range, USA: Geomorphology. 102: 624-639.

Hampel, A., R. Hetzel and A.L. Densmore. 2007. Postglacial slip-rate increase on the Teton normal fault, northern Basin and Range Province, caused by melting of the Yellowstone ice cap and deglaciation of the Teton Range?: Geology. 35(12):1107-1110.

Licciardi, J.M., Clark, P. U., Brook, E. J., Pierce, K. L., Kurz, M. D., Elmore, D. and Sharma, P., 2001, Cosmogenic $3 \mathrm{He}$ and $10 \mathrm{Be}$ chronologies of the late Pinedale northern Yellowstone ice cap, Montana, USA: Geology. 29(12):1095-1098.

Licciardi, J.M. and K.L. Pierce. 2008. Cosmogenic exposure-age chronologies of Pinedale and Bull Lake glaciations in greater Yellowstone and the Teton Range, USA: Quaternary Science Reviews. 27:814-831.

Lippolt, H.J., Leitz, M., R.S. Wenicke and B. Hagedorn. 1994. $(\mathrm{U}+\mathrm{Th})$ Helium dating of apatite - experience from different geochemical environments: Chemical Geology. 112:179-191.

Love, J.D., J.C. Reed and K.L. Pierce. 2003. Creation of the Teton Landscape; a Geologic Chronicle of Jackson Hole and the Teton Range: Grand Teton Natural History Association, Moose, Wyoming, USA.
Nishiizumi, K., C.P. Kohl, J.R. Arnold, R. Dorn, J. Klein, D. Fink, R. Middleton and D. Lal. 1993. Role of in situ cosmogenic nuclides ${ }^{10} \mathrm{Be}$ and ${ }^{26} \mathrm{Al}$ in the study of diverse geomorphic processes: Earth Surface Processes and Landforms. 18:407-425.

Roberts, S.V. and D.W. Burbank. 1993. Uplift and thermal history of the Teton Range (northwestern Wyoming) defined by apatite fission-track dating: Earth and Planetary Science Letters. 118: 295-309.

Ruhl, K.W. and K.V. Hodges. 2005. The use of detrital mineral cooling ages to evaluate steady state assumptions in active orogens: An example from the central Nepalese Himalaya: Tectonics. 24:TC4015-.

Small, E.E., R.S. Anderson, J.L. Repka and R.C. Finkel. 1997. Erosion rates of alpine bedrock summit surfaces deduced from in situ $10 \mathrm{Be}$ and 26Al: Earth and Planetary Science Letters. 150:413-425.

Smith, R.B., J.O.D. Byrd and D.D. Susong. 1993. The Teton fault, Wyoming: Seismotectonics, Quaternary history, and earthquake hazards. In: Geology of Wyoming. A.W. Snoke, J.R. Steidtmann, and S.M. Roberts (eds.) Geological Survey of Wyoming Memoir. 5:628 - 667 .

Stock, G.M., T.A. Ehlers and K.A. Farley. 2006. Where does sediment come from? Quantifying catchment erosion with detrital apatite (U$\mathrm{Th}) / \mathrm{He}$ thermochronometry. 725-728.

Stockli, D.F., K.A. Farley and T.A. Dumitru. 2000. Calibration of the (U-Th)/He thermochronometer on an exhumed fault block, White Mountains, California. Geology. 28:983-986.

Wolf, R.A., K.A. Farley and D.M. Kass. 1998. Modeling of the temperature sensitivity of the apatite (U-Th)/He thermochronometer: Chemical Geology. 148:105-114.

Zeitler, P.K., A.L. Herczeg, I. Mcdougall and M. Honda. 1987. U-Th-He dating of apatite: a potential thermochronometer: Geochima et Cosmochimica Acta. 51:2865-2868. 